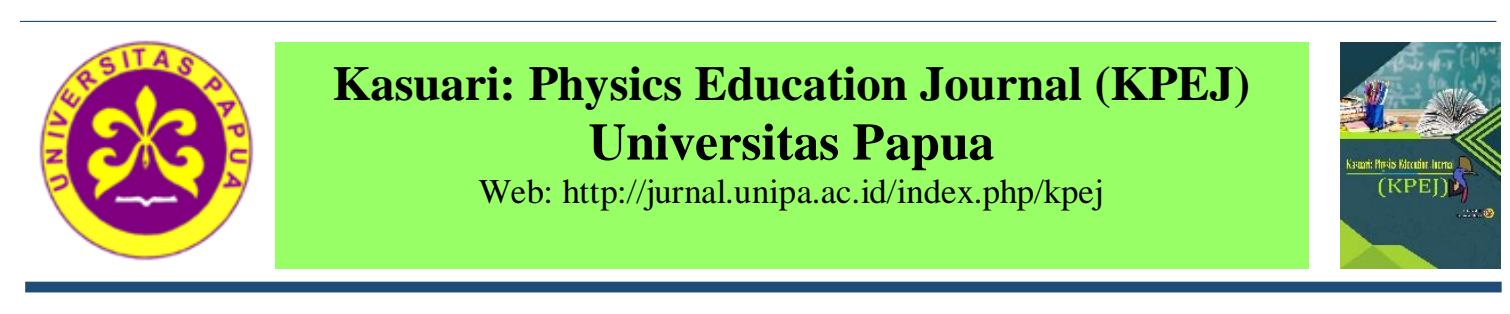

\title{
The Effectiveness of Fluid Physics Practicum Module Based On Wetland Environment to Train Science Process Skills
}

\author{
Zainuddin*, Mastuang, Misbah, Melisa, Fitriana Dewi Ramadhani, Desi Rianti, \& \\ Ida Rusmawati \\ Program Studi Pendidikan Fisika, Fakultas Keguruan dan Ilmu Pendidikan, Universitas Lambung \\ Mangkurat \\ *Corresponding author: Zainuddin_pfis@ulm.ac.id
}

\begin{abstract}
The purpose of this study was to describe the effectiveness of a wetland environment-based practicum module to train students' science process skills. This research was a research and development study with a 4D model (Define, Design, Develop and Disseminate) with the limitations of this research in the form of product effectiveness only. The product has been validated and the result was $89 \%$ categorized as very valid. The subjects of the trial were students of Lambung Mangkurat University Physics Education and the subjects of the distribution stage were Physics Tadris students UIN Antasari. The instrument used in the study was a science process skills assessment sheet, meanwhile the data analysis is done by calculate the $n$-gain on the value of science process skills and accompanied by the average value of each meeting as supporting data. The results shows that this module was effective in the medium category. It can be conclude that this wetland environment-based practicum module is effective for use in lectures.
\end{abstract}

Keywords: practicum module, science process skill, wetland environment

\section{Efektivitas Modul Praktikum Fisika Fluida Berbasis Lingkungan Lahan Basah untuk Melatih Keterampilan Proses Sains}

\begin{abstract}
Abstrak: Tujuan dari penelitian ini adalah untuk mendeskripsikan efektivitas modul praktikum berbasis lingkungan lahan basah untuk melatihkan keterampilan proses sains mahasiswa. Penelitian ini merupakan jenis penelitian dan pengembangan dengan model 4D (Define, Design, Develop and Disseminate) dengan batasan penelitian ini berupa efektivitas produk saja. Produk telah divalidasi dengan hasil $89 \%$ berkategori sangat valid. Subjek dari uji coba berupa mahasiswa Pendidikan Fisika Universitas Lambung Mangkurat dan subjek tahap penyebaran berupa mahasiswa Tadris Fisika UIN Antasari. Instrumen yang digunakan dalam penelitian berupa lembar penilaian keterampilan proses sains, sementara analisis data dilakukan dengan menggunakan $n$-gain terhadap nilai keterampilan proses sains dan disertai dengan nilai rata-rata tiap pertemuan sebagai data pendukung. Hasil penelitian menunjukkan bahwa modul ini efektif dengan kategori sedang. Dapat disimpulkan bahwa modul praktikum berbasis lingkungan lahan basah ini efektif digunakan di perkuliahan.
\end{abstract}

Kata kunci: keterampilan proses sains, lingkungan lahan basah, modul praktikum.

\section{PENDAHULUAN}

Pada perguruan tinggi, fisika dipelajari secara spesifik kedalam cabang-cabang fisika tertentu. Salah satunya adalah fisika yang berkaitan denga zat cair dan gas, yang disebut fluida. Pada Program Studi Pendidikan Fisika, mata kuliah Fisika Fluida adalah mata kuliah wajib yang harus dipelajari oleh mahasiswa. Tujuan dari perkuliahan Fisika Fluida adalah mahasiswa dapat menjelaskan konsep-konsep fluida dalam kehidupan sehari-hari dan dapat melakukan verifikasi konsep tersebut melalui penyelidikan atau praktikum 
(Wahyudi \& Lestari, 2019). Kegiatan praktikum dapat memiliki keunggulan diantaranya adalah mahasiswa dapat terlibat aktif dalam perkuliahan sehingga dapat memperoleh keterampilan proses sains dan melatihkan sikap ilmiah selama praktikum berlangsung (Misbah, Wati, Rif'at, \& Prastika, 2018; Rohman \& Lusiyana, 2017). Keterampilan proses sains ini merupakan pengembangan dari pendekatan saintifik yang ingin dicapai dalam menghasilkan potensi lulusan mahasiswa yang memiliki keseimbangan soft skill dan hard skill (Rosmalinda, Rusdi, \& Hariyadi, 2014).

Fisika fluida memiliki banyak fenomena dalam kehidupan sehari-hari. Hal ini merupakan suatu keuntungan yang dapat dimanfaatkan dosen untuk membantu proses mentransfer pengetahuan kepada mahasiswa. Salah satu fenomena yang dapat dikaji dalam mata kuliah fisika fluida adalah fenomena-fenomena yang terjadi di lingkungan lahan basah. Lahan basah merupakan wilayah yang memiliki air yang tergenang atau mengalir yang kedalamannya saat pasang rendah tidak lebih dari 6 meter (Soendjoto, 2015). Secara geografis, Kalimantan Selatan memiliki wilayah lahan basah yang sangat luas. Keunggulan inilah yang menjadi nilai sorot Universitas Lambung Mangkurat (ULM) dalam visinya yaitu agar terwujudnya Universitas Lambung Mangkurat menjadi universitas terkemuka dan berdaya saing tinggi di bidang lingkungan lahan basah. Hal ini menuntut dosen agar dapat menyisipkan lingkungan lahan basah, salah satunya dengan menjadikan sumber belajar atau objek masalah (Dewantara et al., 2020; Iriani, Herlina, Irhasyuarna, \& Sanjaya, 2019; Yunita, Saadi, \& Kusasi, 2018; Zainuddin \& Misbah, 2020). Dengan begitu, diharapkan proses perkuliahan yang berbasis lingkungan lahan basah akan menghilangkan kejenuhan dan membuat perkuliahan menjadi lebih bermakna.

Namun pada perkuliahannya, menurut hasil wawancara dan observasi dengan dosen pada mata kuliah fisika fluida, keterampilan proses sains mahasiswa masih belum dilatihkan secara optimal. Hal ini menyebabkan mahasiswa masih belum terampil dalam proses sains. Penggunaan bahan ajar seperti modul praktikum yang digunakan dalam mata kuliah ini juga belum berbasis lingkungan lahan basah sebagaimana visi ULM dan visi Program Studi Pendidikan Fisika ULM sehingga mahasiswa masih kurang memahami penerapan konsep yang telah dipelajari di dalam kehidupan.

Salah satu solusi untuk mengatasi permasalahan tersebut adalah dengan mengembangkan modul praktikum sebagai salah satu sumber belajar yang berbasis lingkungan sekitar. Modul ini diharapkan efektif dalam melatihkan keterampilan proses sains dan dapat memudahkan mahasiswa dalam memahami materi perkuliahan dengan mengenal lingkungan lahan basah.

Berbagai penelitian yang relevan menunjukkan produk berbasis lahan basah efektif digunakan dalam pembelajaran. Hasil penelitian oleh Ihsan et al. (2017) menunjukkan produk pembelajaran yang berbasis lingkungan lahan basah efektif dan dapat digunakan untuk melatihkan keterampilan proses sains. Penelitian oleh Selvia et al. (2018) menunjukkan bahwa bahan ajar fisika berorientasi lingkungan lahan basah melalui pendekatan contextual teaching and learning memiliki validitas tinggi, praktikalitas baik dan efektivitas berkategori tinggi. Hal serupa juga didapat dari penelitian Aini et al. (2018) dan Zainuddin et al. (2018) yang juga memiliki efektivitas yang baik sehingga bahan ajar dapat diterapkan selama proses belajar mengajar.

Modul praktikum fisika fluida yang dikembangkan mengintegrasikan lingkungan lahan basah yang merupakan ciri khas dari Universitas Lambung Mangkurat, dan belum pernah dikembangkan sebelumnya modul tersebut untuk mata kuliah fisika fluida. Disamping itu, penyajian masalah di awal modul praktikum dikaitkan dengan lingkungan lahan basah yang merupakan objek masalah yang dekat dengan kehidupan mahasiswa. 
Namun, untuk mendapatkan modul praktikum berbasis lingkungan lahan basah yang baik, maka bahan ajar harus dinilai kelayakannya. Salah satu aspek kelayakan tersebut adalah efektivitas. Produk ini telah divalidasi oleh validator ahli dengan kategori sangat valid, sehingga penelitian ini dilakukan untuk mendeskripsikan efektivitas modul praktikum berbasis lingkungan lahan basah untuk melatih sikap ilmiah dan keterampilan proses sains mahasiswa.

\section{METODE PENELITIAN}

Jenis penelitian ialah penelitian dan pengembangan. Produk yang dikembangkan berupa modul praktikum berbasis lingkungan lahan basah untuk melatihkan keterampilan proses sains. Penelitian ini menggunakan model 4D (Define, Design, Develop and Disseminate). Tahap define merupakan tahap menganalisis capaian pembelajaran mata kuliah, karakteristik materi dan karakteristik mahasiswa pada mata kuliah Fisika Fluida. Tahap design merupakan tahap merancang produk yang akan dikembangkan dengan menggunakan strategi perkuliahan yang sesuai dengan masalah yang ada. Tahap develop adalah tahap mengembangkan modul praktikum, melakukan validasi produk, melakukan ujicoba skala kecil dan skala besar, evaluasi dan revisi. Produk ini telah diuji validitasnya dengan hasil $89 \%$ dan terkategori sangat valid. Tahap disseminate merupakan tahap menyebarkan modul praktikum pada kalangan mahasiswa. Pada artikel ini lebih dibahas pada bagian efektivitas produk yang dikembangkan.

Efektivitas produk dapat dilihat dari uji n-gain (Misbah Misbah, Hirani, Annur, Sulaeman, \& Ibrahim, 2020). Instrumen penelitian yang digunakan lembar penilaian keterampilan proses sains mahasiswa. Data dianalisis dengan menghitung $n$-gain pretest dan posttest. Produk diujicobakan pada skala kecil dan besar kepada 15 orang mahasiswa Pendidikan Fisika Universitas Lambung Mangkurat. Setelah dilakukan evaluasi dan revisi, produk kemudian disebarkan kepada 18 orang mahasiswa Tadris Fisika UIN Antasari. Hasil perhitungan n-gain terhadap mahasiswa ULM dan UIN Antasari diperoleh dari rumus n-gain dan kemudian dibandingkan dengan tabel kategori efektivitas Hake (1998).

\section{HASIL DAN PEMBAHASAN}

Penelitian ini menggunakan prosedur pengembangan 4D dengan tujuan menghasilkan modul praktikum Fisika Fluida yang efektif sehingga layak untuk digunakan selama perkuliahan.

\section{Tahap define}

Pada tahap ini dilakukan analisis terhadap capaian mata kuliah, masalah dalam perkuliahan, karakteristik materi dan karakteristik mahasiswa pada kelas ujicoba dan kelas penyebaran. Hasil analisis tahap ini adalah: (1) mata kuliah fisika fluida memiliki materi yang memerlukan keterampilan prosedural sehingga perkuliahan melalui percobaan diperlukan agar mahasiswa terlibat aktif, (2) mata kuliah fisika fluida tidak memiliki modul praktikum sehingga mahasiswa kekurangan sumber belajar, (3) Kurangnya bahan ajar perkuliahan yang berbasis lingkungan lahan basah, (4) sikap ilmiah dan keterampilan proses sains tidak dilatihkan secara optimal, (5) mahasiswa masih belum terampil terhadap keterampilan proses sains. Selain itu, pada tahap ini juga dilakukan perumusan terhadap materi apa saja yang dapat dicantumkan pada modul praktikum.

\section{Tahap design}

Pada tahap ini dilakukan perancangan modul praktikum. Modul praktikum dikembangkan dengan basis lingkungan lahan basah. Lingkungan lahan basah menjadi 
objek masalahan disetiap awal modul praktikum. Hal ini dirancang agar mahasiswa mendapat gambaran mengenai penerapan materi praktikum tersebut dalam kehidupan. Di samping itu, mahasiswa juga dibimbing untuk menjelaskan contoh penerapan lainnya di lingkungan lahan basah. hal ini akan memicu mahasiswa berpikir kristis. Keterampilan proses sains dicantumkan pada setiap tahapan dalam modul. Hal ini akan memudahkan mahasiswa untuk memfokuskan mereka keterampilan apa saja yang dilatihkan pada tahapan praktikum tersebut. Di samping itu, peneliti juga akan lebih mudah dalam menilai keterampilan proses sains mahasiswa karena petunjuk yang jelas.

Pemilihan media juga dipertimbangkan untuk kemudahan mahasiswa. Beberapa praktikum dapat dilakukan dengan menggunakan simulator PhET. Praktikum yang menggunakan simulator sudah disertai link simulator dan langkah-langkah praktikum disertai dengan gambar dan petunjuk yang jelas. Namun, untuk tetap membiasakan mahasiswa terampil dalam menggunakan alat-alat labratorium, odul praktikum ini juga menyediakan beberapa praktikum yang memerlukan komponen dari alat-alat laboratorium.

\section{Tahap develop}

Pada tahap ini, modul praktikum dikembangkan sesuai rancangan pada tahap sebelumnya. Hasil dari pengembangan tersebut dapat dilihat pada gambar 1.

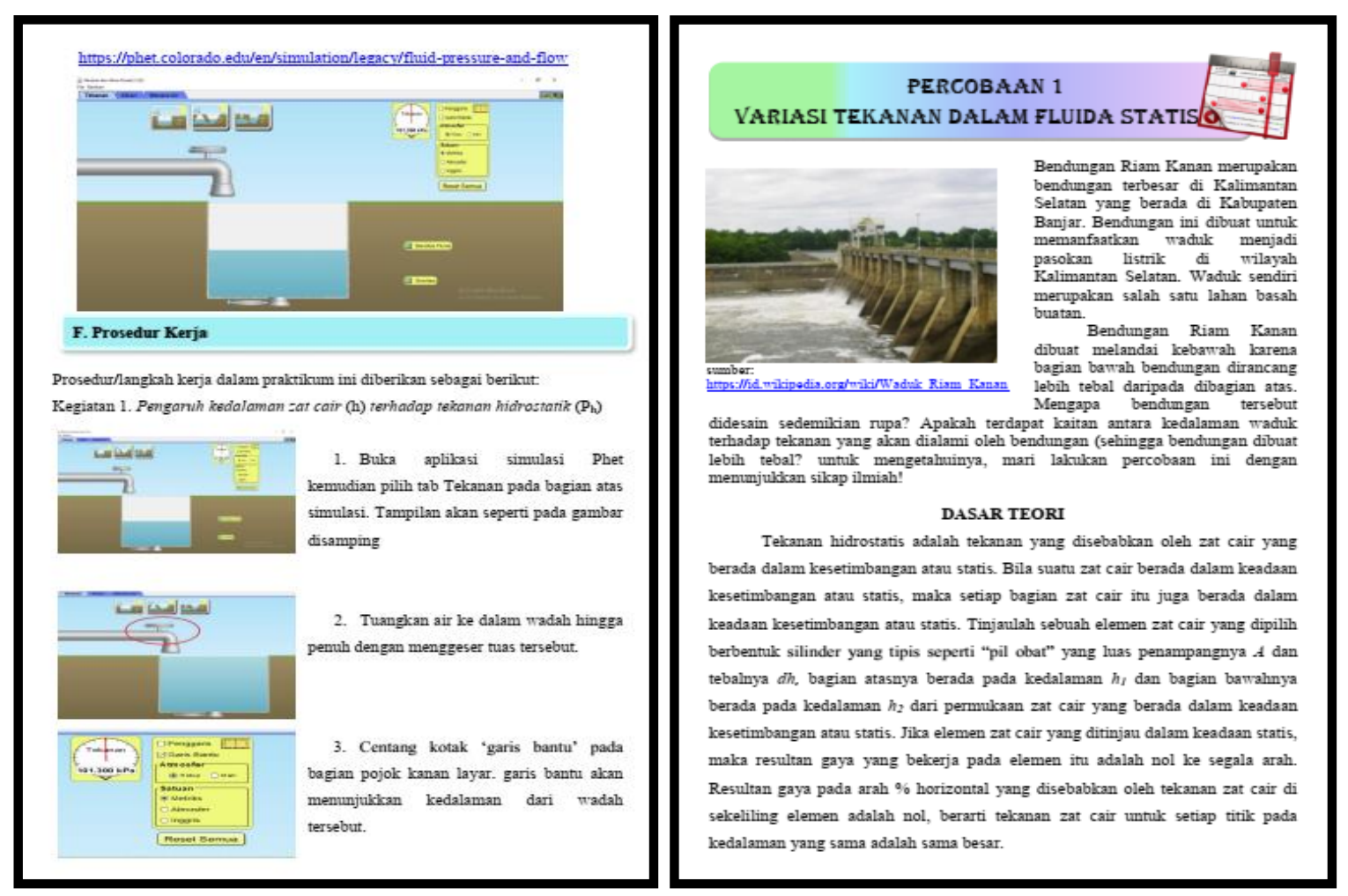

Gambar 1. Bagian awal dan prosedur kerja dalam modul praktikum

Setelah dikembangkan, maka produk divalidasi oleh validator ahli, dan hasilnya menunjukkan bahwa modul praktikum ini sangat valid dengan persentase $89 \%$. Selanjutnya produk diiuji cobakan pada mahasiswa Pendidikan Fisika FKIP ULM. Hasil perhitungan $n$-gain keterampilan proses sains pada kelas uji coba dapat dilihat pada tabel 1. Sebagai data pendukung, maka pada tabel 1 juga disediakan hasil rata-rata keterampilan proses sains pada tiga pertemuan untuk melihat peningkatan pada tiap pertemuan. 
Tabel 1. Hasil perhitungan n-gain keterampilan proses sains kelas ujicoba

\begin{tabular}{|l|c|c|c|c|c|}
\hline \multirow{2}{*}{\multicolumn{1}{c|}{ Aspek KPS }} & \multicolumn{5}{c|}{ Kelas Uji coba } \\
\cline { 2 - 6 } & Pretest & Posttest & P1 & P2 & P3 \\
\hline Merumuskan Masalah (M1) & 2.20 & 3.67 & 3.64 & 3.73 & 3.73 \\
\hline Merumuskan Hipotesis (M2) & 2.14 & 3.53 & 2.87 & 2.87 & 3.80 \\
\hline Mengidentifikasi Variabel (M3) & 1.80 & 3.33 & 3.50 & 3.57 & 3.47 \\
\hline Mendefinisikan Variabel (M4) & 0.87 & 3.40 & 2.53 & 3.07 & 3.40 \\
\hline Mengumpulkan data (M5) & 1.07 & 3.20 & 3.00 & 3.27 & 3.47 \\
\hline Menganalisis data (M6) & 0.40 & 2.85 & 3.00 & 2.87 & 3.07 \\
\hline Menarik kesimpulan (M7) & 0.40 & 2.47 & 3.47 & 3.27 & 3.27 \\
\hline Mengkomunikasikan (M8) & 1.00 & 1.67 & 2.67 & 2.73 & 3.07 \\
\hline$N$-gain & \multicolumn{7}{c|}{0.67} & & & \\
\hline Kategori Efektivitas & \multicolumn{7}{|c|}{ Sedang } & & \\
\hline
\end{tabular}

Berdasarkan hasil dari tabel 1, hasil n-gain tersebut menunjukkan terdapat perbedaan pada hasil keterampilan proses sains sebelum dan sesudah menggunakan modul praktikum berbasis lingkungan lahan basah. Hasil posttest yang meningkat dibandingkan hasil pretest dapat memberikan gambaran bahwa pada kelas ujicoba, modul praktikum ini dapat melatihkan keterampilan proses sains pada mahasiswa dengan nilai selisih antara dua tes tersebut berupa 0.67 dengan kategori sedang. Untuk melihat ketercapaian keterampilan proses tiap indikator pada kelas ujicoba dapat dilihat pada gambar 2 .

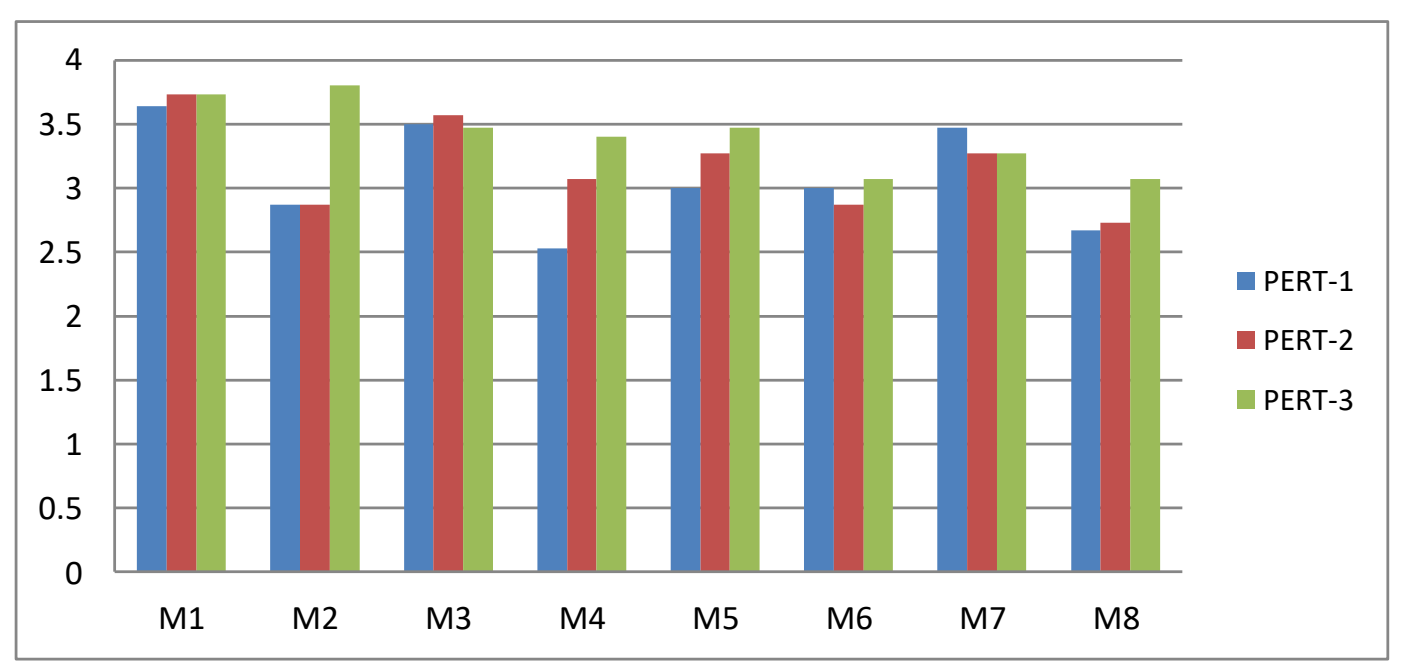

Gambar 2. Grafik ketercapaian keterampilan proses sains mahasiswa kelas uji coba

Gambar 2 terlihat bahwa keterampilan yang memiliki rata-rata paling tinggi pada kelas uji coba adalah merumuskan masalah. Sedangkan untuk rata-rata paling rendah adalah aspek mengkomunikasikan. Aspek merumuskan masalah adalah aspek yang paling mudah dilatihkan karena mahasiswa dapat membuat rumusan masalah berdasarkan tujuan percobaan. Sedangkan aspek mengkomunikasikan memiliki nilai yang paling rendah dikarenakan penelitian dilakukan secara daring sehingga menyulitkan 
mahasiswa dalam menyampaikan hasil percobaan secara berkelompok maupun secara individu.

\section{Tahap disseminate}

Setelah melalui tahap uji coba, produk disebarkan kepada mahasiswa Tadris Fisika UIN Antasari sebagai lokasi penyebaran. Efektivitas modul praktikum dilihat dari uji ngain keterampilan proses sains mahasiswa. Hasil uji tersebut dapat dilihat pada tabel 2. Sebagai data pendukung, maka pada tabel 2 juga disediakan hasil rata-rata keterampilan proses sains pada tiga pertemuan untuk melihat peningkatan pada tiap pertemuan

Tabel 2. Hasil perhitungan $n$-gain keterampilan proses sains pada tahap disseminate

\begin{tabular}{|l|c|c|c|c|c|}
\hline \multirow{2}{*}{\multicolumn{1}{|c|}{ Aspek KPS }} & \multicolumn{6}{c|}{ Kelas Besar } \\
\cline { 2 - 7 } & Pretest & Postest & P1 & P2 & P3 \\
\hline Merumuskan Masalah (M1) & 2.72 & 4.00 & 3.12 & 3.44 & 3.89 \\
\hline Merumuskan Hipotesis (M2) & 0.44 & 2.67 & 2.19 & 2.78 & 3.28 \\
\hline Mengidentifikasi Variabel (M3) & 0.35 & 3.11 & 2.59 & 3.06 & 3.17 \\
\hline Mendefinisikan Variabel (M4) & 0.00 & 2.78 & 1.38 & 2.33 & 3.11 \\
\hline Mengumpulkan data (M5) & 1.11 & 2.89 & 2.53 & 3.00 & 3.11 \\
\hline Menganalisis data (M6) & 0.11 & 2.39 & 2.65 & 2.88 & 2.94 \\
\hline Menarik kesimpulan (M7) & 0.00 & 2.72 & 2.25 & 3.00 & 2.72 \\
\hline Mengkomunikasikan (M8) & 1.11 & 2.06 & 1.94 & 2.83 & 3.28 \\
\hline$N$-gain & \multicolumn{3}{|c|}{0.68} & & \\
\hline Kategori Efektivitas & \multicolumn{7}{|c|}{ Sedang } \\
\hline
\end{tabular}

Sama seperti pada kelas uji coba, hasil n-gain pada kelas penyebaran juga menunjukkan perbedaan hasil sebelum dan sesudah menggunakan produk. Pada tabel 2, hasil n-gain pada kelas penyebaran menunjukkan angka 0.68 dengan kategori sedang. Hasil tersebut tidak jauh berbeda dengan hasil kelas uji coba. Hal ini menggambarkan bahwa pada kelas penyebaran, modul praktikum berbasis lingkungan lahan basah ini dapat melatihkan keterampilan proses sains pada mahasiswa. Peningkatan juga terjadi pada hasil keterampilan proses sains pada tiap pertemuan. Untuk melihat ketercapaian keterampilan proses tiap indikator pada kelas ujicoba dapat dilihat pada gambar 3 .

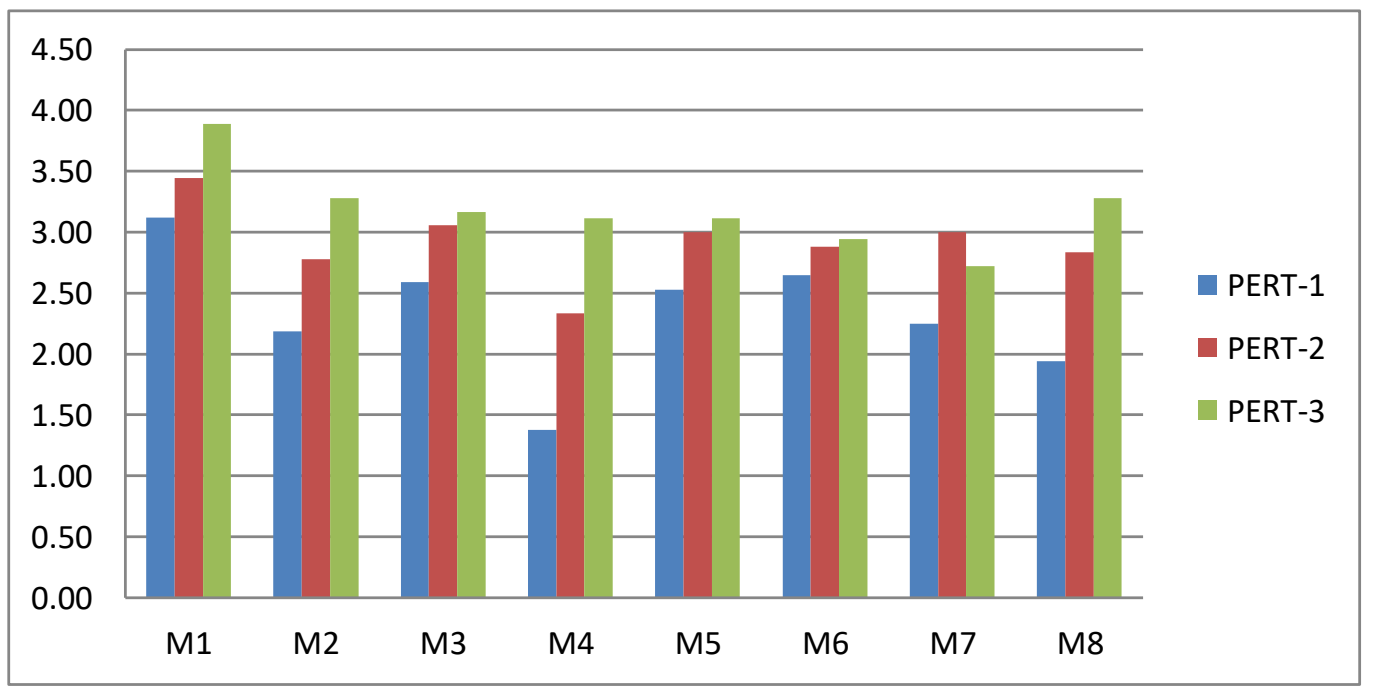

Gambar 3. Grafik ketercapaian keterampilan proses sains mahasiswa di tahap disseminate 
Gambar 3 menunjukkan bahwa aspek merumuskan masalah memiliki nilai rata-rata tertinggi baik pada kelas uji coba maupun kelas penyebaran. Sedangkan aspek menarik kesimpulan memiliki nilai rata-rata terendah pada kelas penyebaran ini. Tabel 1 dan tabel 2 menunjukkan bahwa nilai n-gain untuk kedua kelas memiliki kategori sedang.

Efektivitas modul praktikum yang dikembangkan dilihat dari $n$-gain keterampilan proses sains mahasiswa selama praktikum berlangsung. Hasil rata-rata $n$-gain untuk kelas kecil dan kelas besar sama-sama berkategori sedang. Nilainya pun tidak jauh berbeda. Hal ini menunjukkan bahwa baik uji coba pada skala kecil,maupun skala besar, modul yang dikembangkan menunjukkan nilai efektivitas yang konsisten.

Walaupun hasil efektivitas hanya berkategori sedang, namun modul yang dikembangkan dapat dikatakan efektif. Hal ini dikarenakan terjadi peningkatan nilai posttest jika dibandingkan dengan pretest. Peningkatan ini disebabkan karena selama proses perkuliahan, mahasiswa beradaptasi untuk menjadi lebih aktif melalui aktivitas praktikum. Aktivitas ini akan membantu mahasiswa dalam melatihkan keterampilan proses sains dan sikap ilmiah sehingga mereka terbiasa untuk merumuskan masalah, merumuskan hipotesis, mengidentifikasi dan mendefinisikan variabel, mengumpulkan data, menganalisis data, menarik kesimpulan dan mengkomunikasikan. Hal ini sejalan dengan penelitian yang dilakukan oleh Malik et al (2015) yang juga menghasilkan modul praktikum keterampilan proses sains yang efektif untuk mahasiswa dalam perkuliahan.

Peningkatan nilai mahasiswa juga dapat disebabkan oleh penyisipan lingkungan lahan basah dalam pembelajaran. Lingkungan lahan basah tersebut akan mendukung tujuan perkuliahan karena pemberian masalah dikaitkan dengan kehidupan sehari-hari (Arends, 2013). Penelitian oleh Ihsan et al. (2019) dan Misbah et al. (2018) juga sejalan dengan pendapat Arends yang menyatakan bahwa pelajar akan lebih termotivasi dalam belajar jika mereka diberikan representasi materi di lingkungan sekitarnya. Lingkungan lahan basah sebagai motivasi pembelajaran juga dapat menigkatkan hasil belajar (Wati \& Misbah, 2020). Hasil penelitian Yuliyanti (2016) juga senada dengan penelitian sebelumnya yang menyatakan bahwa pembelajaran dengan basis lingkungan sekitar mahasiswa dapat mengembangkan keterampilan dan sikap yang sesuai selama pembelajaran.

\section{SIMPULAN DAN SARAN}

Berdasarkan hasil ujicoba dan hasil penyebaran yang telah dilakukan terhadap modul praktikum fisika fluida berbasis lingkungan lahan basah diperoleh hasil efektivitas modul berkategori sedang. Dapat disimpulkan bahwa modul praktikum berbasis lingkungan lahan basah ini efektif digunakan pada perkuliahan untuk melatih keterampilan proses sains mahasiswa.

\section{UCAPAN TERIMAKASIH}

Peneliti mengucapkan terima kasih banyak kepada Unievrsitas Lambung Mangkurat (ULM) dan LPPM ULM melalui pendanaan PNBP Universitas tahun 2020 dengan program "dosen wajib meneliti".

\section{DAFTAR PUSTAKA}

Aini, N., Zainuddin, Z., \& Mahardika, A. I. (2018). Pengembangan Materi Ajar IPA Menggunakan Model Pembelajaran Kooperatif Berorientasi Lingkungan Lahan Basah. Berkala Ilmiah Pendidikan Fisika, 6(2), 264. https://doi.org/10.20527/bipf.v6i2.4919 
Arends, R. (2013). Belajar untuk mengajar buku 2 (9th ed.). Jakarta: Salemba Humanika. Dewantara, D., Zainuddin, Z., Wati, M., Suyidno, S., Misbah, M., Haryandi, S., ... Munir, M. J. M. (2020). Training and assistance in preparing class action research proposals for science teachers in Hulu Sungai Tengah regency. Indonesian Journal of Science and Education, 4(1), 30-34.

Hartini, S., Firdausi, S., Misbah, \& Sulaeman, N. F. (2018). The development of physics teaching materials based on local wisdom to train Saraba Kawa characters. Jurnal Pendidikan IPA Indonesia, 7(2), 130-137. https://doi.org/10.15294/jpii.v7i2.14249

Ihsan, I. N., Jamal, M. A., \& Salam, A. (2017). Pengembangan perangkat pembelajaran berorientasi lingkungan sekitar bantaran sungai barito untuk melatihkan keterampilan proses sains. Berkala Ilmiah Pendidikan Fisika, 5(1), 29-45.

Ihsan, I., Yulkifli, \& Festiyed. (2019). Analysis of electronic module development using model inquiry based learning with approach contextual teaching and learning in physics material of senior high school class X. Journal of Physics: Conference Series, 1317(1), 0-5. https://doi.org/10.1088/1742-6596/1317/1/012160

Iriani, R., Herlina, A., Irhasyuarna, Y., \& Sanjaya, R. E. (2019). Modul pembelajaran problem-based learning berbasis lahan basah untuk mempersiapkan calon pendidik berwawasan lingkungan lahan basah Problem-based learning module based on wetland to prepare teachers candidate with wetland environmental insight. Jurnal Inovasi Pendidikan IPA, 5(1), 54-68.

Malik, A., Handayani, W., \& Nuraini, R. (2015). Model Praktikum Problem Solving Laboratory untuk Meningkatkan Keterampilan Proses Sains Mahasiswa. Prosiding Simposium Nasional Inovasi Dan Pembelajaran Sains 2015, 193-196.

Misbah, M, Wati, M., Rif'at, M. F., \& Prastika, M. D. (2018). Pengembangan petunjuk praktikum fisika dasar i berbasis $5 \mathrm{M}$ untuk melatih keterampilan proses sains dan karakter wasaka. Jurnal Fisika Flux: Jurnal Ilmiah Fisika FMIPA Universitas Lambung Mangkurat, 15(1), 26-30.

Misbah, Misbah, Dewantara, D., \& Mahtari, S. (2018). Physics Learning Based on Wetlands and Banjar Culture. International Journal of Applied and Physical Sciences, 4(1), 21-28. https://doi.org/10.20469/ijaps.4.50004-1

Misbah, Misbah, Hirani, M., Annur, S., Sulaeman, N. F., \& Ibrahim, M. A. (2020). The Development and Validation of a Local Wisdom-Integrated Physics Module to Grow the Students' Character of Sanggup Bagawi Gasan Masyarakat. JIPF (Jurnal Ilmu Pendidikan Fisika), 5(1), 1. https://doi.org/10.26737/jipf.v5i1.1280

R. R. Hake. (1998). Interactive-Engagement Versus Traditional Methods: A SixThousand-Student Survey of Mechanics Test Data for Inductory Physics Courses. American Journal of Physics, 66(1), 65-74.

Rohman, F., \& Lusiyana, A. (2017). Pengembangan Modul Praktikum Mandiri Sebagai Asesmen Keterampilan Proses Sains dan Keterampilan Sosial Mahasiswa. JIPFRI (Jurnal Inovasi Pendidikan Fisika Dan Riset Ilmiah), 1(2), 47-56. https://doi.org/10.30599/jipfri.v1i2.115

Rosmalinda, D., Rusdi, M., \& Hariyadi, B. (2014). Pengembangan Modul Praktikum Kimia SMA Berbasis PBL(Problem Based Learning). Edu-Sains: Jurnal Pendidikan Matematika Dan Ilmu Pengetahuan Alam, 2(2). https://doi.org/10.22437/jmpmipa.v2i2.1666

Selvia, M., Arifuddin, M., \& Mahardika, A. I. (2018). Pengembangan Bahan Ajar Fisika SMA Topik Fluida Berorientasi Masalah Lahan Basah Melalui Pendekatan Contextual Teaching and Learning (CTL). Berkala Ilmiah Pendidikan Fisika, 5(2), 213. https://doi.org/10.20527/bipf.v5i2.2896 
Soendjoto, M. A. (2015). Sekilas Tentang Lahan Basah dan Lingkungannya. Prosiding Seminar Universitas Lambung Mangkurat, 1-20.

Wahyudi, W., \& Lestari, I. (2019). Pengaruh Modul Praktikum Optika Berbasis Inkuiri Terhadap Keterampilan Proses Sains dan Sikap Ilmiah Mahasiswa. Jurnal Pendidikan Fisika Dan Keilmuan (JPFK), 5(1), 33-44.

Wati, M., \& Misbah, M. (2020). The Practicality of Physics Teaching Materials Based on the Wetland Environment. Proceeding of 1st South Borneo International Conference on Sport Science and Education 2019, 407, 185-187. https://doi.org/10.2991/assehr.k.200219.058

Yuliyanti, N. (2016). Pengaruh Model Inkuiri Terbimbing Berbasis Lingkungan Terhadap Kemampuan Pemahaman Konsep dan Karakter. Jurnal Cakrawala Pendas, 2(2), 1-10.

Yunita, A., Saadi, P., \& Kusasi, M. (2018). Pemanfaatan Sumber Belajar dari Lingkungan Lahan Basah Melalui Pendekatan CTL terhadap Hasil Belajar pada Pembelajaran Larutan Asam Basa. Prosiding Seminar Nasional Pendidikan Kimia, $20-28$.

Zainuddin, Z., Afnizar, H. A., Mastuang, M., \& Misbah, M. (2018). Developing a teaching material oriented to science and technology and local wisdom in wetland environment. 1st International Conference on Creativity, Innovation and Technology in Education (IC-CITE 2018. Atlantis Press.

Zainuddin, Z., \& Misbah, M. (2020). Validasi perangkat pembelajaran fisika fluida berbasis lingkungan lahan basah. Prosiding Seminar Nasional Lingkungan Lahan Basah, 5(2), 30-35. 